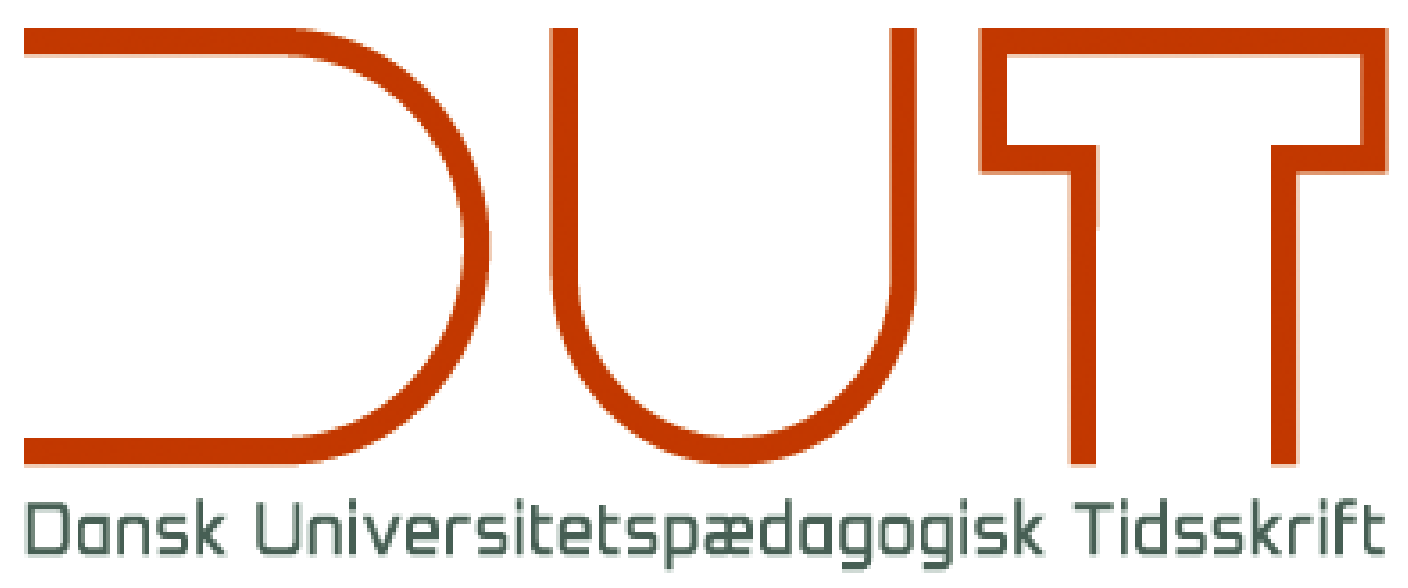

Læringsrum

Årgang 14 nr. 27 / 2019

Titel

DUT Guide: Undervisningens indholdsvalg

Forfattere

Sidetal

Tina Bering Keiding

$177-187$

Udgivet af

Dansk Universitetspædagogisk Netværk, DUN

URL

> http://dun-net.dk/

Betingelser for brug af denne artikel

(c) Copyright
Denne artikel er omfattet af ophavsretsloven, og der må citeres fra den. Følgende betingelser skal dog være opfyldt:

- Citatet skal være i overensstemmelse med "god skik"

- Der må kun citeres „i det omfang, som betinges af formålet“

- Ophavsmanden til teksten skal krediteres, og kilden skal angives ift. ovenstående bibliografiske oplysninger.

DUT og artiklens forfatter 


\title{
DUT Guide: Undervisningens indholdsvalg
}

\author{
Tina Bering Keiding ${ }^{a, 1}$ \\ ${ }^{a}$ Center for Undervisningsudvikling og Digitale Medier, Aarhus Universitet
}

\begin{abstract}
Spørgsmålet om undervisningens indhold er på en og samme tid et af de helt centrale og mest upåagtede spørgsmål i de videregående uddannelsers didaktik. I hvert fald når vi ser på forskningen. I praksis vælges indhold i hver eneste undervisningssituation. Artiklen præsenterer analytiske begreber og anvisninger, der kan guide underviserens valg af indhold. Udgangspunktet er den tyske almendidaktik, hvor spørgsmålet om undervisningens indhold traditionelt har indtaget en central plads, og som derfor tilbyder en række begreber, der kan skærpe vores analyser af og beslutninger om undervisningens indhold. Selvom jeg trækker tråde tilbage til didaktiske teorier, er det følgende mit kondensat af et mangfoldigt teorifelt og erfaringer fra lige så mangfoldige praksisser.
\end{abstract}

\section{Praksispunkter}

1. Hav mod til at vælge fra

2. Udvælg eksemplariske eksempler og gør det eksemplariske/det generiske tydeligt

3. Tag højde for de studerendes faglige forudsætninger

4. Overvej om der er indhold, der er særligt interessant for de studerende

5. Overvej om og hvornår forskningen kan bidrage med værdifuldt indhold

6. Forhold dig nuanceret til aftagernes ønsker

7. Se dit fag som en helhed og som en del af den samlede uddannelse

\section{Baggrund}

Den almene universitetspædagogiske litteratur beskæftiger sig altovervejende med undervisningsmetoder og tilbyder kun ganske få didaktiske refleksioner om undervisningens indhold. Dette gælder både, når vi vender blikket mod den empiriske og praksisnære forskning og i de mere konceptuelt og alment orienterede lærebøger (Keiding \& Qvortrup, 2017). En af de få undtagelser finder vi i Ulriksen (2014: 121ff.). Én mulig forklaring på den manglende interesse for indholdsspørgsmålet kunne være, at det stærke fokus på kompetencer og læringsmål, der opstod i tilknytning til Bologna processen (EU, 2015), har forskudt den didaktiske og forskningsmæssige opmærksomhed fra undervisningens indhold til undervisningens formål og mål, men heller ikke spørgsmålet om undervisningens formål og læringsmål er et

\footnotetext{
${ }^{1}$ Kontakt: keiding@tdm.au.dk
} 
centralt forskningstema (Keiding \& Qvortrup, 2017). En anden forklaring kan være "from teaching to learning"- paradigmet, som førte til en markant forskydning af den didaktiske opmærksomhed fra formidling af indhold til spørgsmål om aktiverende undervisningsformer (Barr \& Tagg, 1995; Keiding \& Qvortrup, 2017; Qvortrup \& Keiding, 2016). Og en tredje mulighed, at netop indholdsvalget er så tæt på faget, at den mere alment orienterede litteratur har vanskeligt ved at sige noget substantielt herom. Men heller ikke det fagdidaktiske tidsskrift, der analyseres i Keiding og Qvortrup (2017), tildeler indholdsspørgsmålet nævneværdig opmærksomhed.

Denne manglende opmærksomhed betyder ikke, at indholdsspørgsmålet er trivielt, hverken didaktisk eller i forhold til fagmiljøernes indre dynamikker og strukturer. Også kompetenceog målstyrede uddannelser har brug for at foretage et valg omkring indholdet i undervisningen. Den tyske didaktik, som jeg læner mig op ad her, er ikke uforenelig med kompetenceorienteret undervisning og de mere mål- og metodeorienterede didaktikker, som vi kender fra fx Biggs and Tang (2011) eller den curriculære didaktik, fx Möller (1973) og Keiding (2013). Tværtimod er den et relevant supplement til disse, fordi den giver mulighed for at stille andre didaktiske spørgsmål og give andre didaktiske svar. Vigtigheden af at forholde sig didaktisk analytisk til indholdsvalget understreges af, at programmerne for uddannelserne, og dermed også indholdet, fastlægges lokalt og dermed er en del af både den interne uddannelsespolitiske og praktisk-didaktiske hverdag.

Indholdsanalysen rummer tre didaktiske spørgsmål. For det første, spørgsmålet om hvad der tematiseres i et konkret forløb; det være sig en hel uddannelse, et fag eller en enkelt session. For det andet, spørgsmålet om for hvem, det tematiseres og for det tredje, hvornår i forløbet, de studerende skal møde indholdet. Hopmann, Künzli, and Jacobsen (1995) beskriver disse spørgsmål, som spørgsmålene om henholdsvis orden; udvalg og roekkefølge. Dermed bliver det muligt at analysere og begrunde indholdsvalg i tre meningsdimensioner, nemlig en saglig, en social og en tidslig dimension (se evt. Luhmann, 2000: 98ff.). Koblingen til meningsbegrebet understreger, at der er tale om analytiske distinktioner, og at betydningen eller værdien af et givet indhold altid formes af samspillet mellem alle tre dimensioner. Udgangspunktet for indholdsanalysen er derfor, at et givet tema altid kan og bør analyseres og begrundes $\mathrm{i}$ forhold til alle tre dimensioner.

Figur 1 indplacerer nogle af de vigtige didaktiske spørgsmål i relation til udvælgelse og begrundelse af indhold i forhold til de tre dimensioner. Spørgsmålene er på den ene side inspireret af Klafiks dannelsesteori (Klafki, 1983) og model for indholdsanalyse (Klafki, 2000), og på den anden side tilpasset på en sådan måde, at de særligt i forhold til udvalgsdimension, indfanger det særlige, der knytter sig til, at universiteterne bedriver forskningsbaseret uddannelse og oplever et stigende fokus på arbejdsmarkedets oplevelse af relevansen af dimittendernes kompetence (for en kort uddybning af begge begreber, se Keiding, 2018). 
1. Det fundamentale

2. Det eksemplariske og det kategoriale

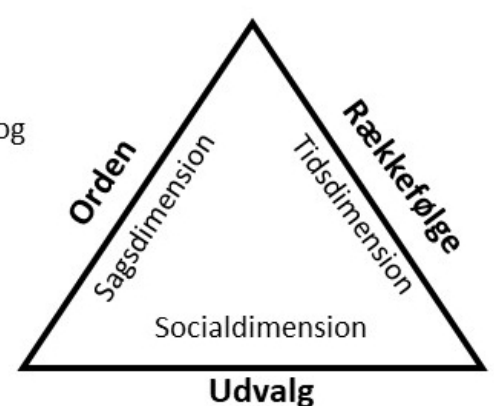

Udvalg
7. Organisering af indholdet i det enkelte fag og i uddannelsen som helhed (forudsætninger og progression)

3. De studerendes faglige forudsætninger og diversiteten i disse

4. De studerendes interesser

5. Forskningsbasering

6. Betydning for de studerendes fremtidige karriere

Figur 1. De tre dimensioner for analyse og begrundelse af indholdsvalg samt de 7 didaktiske temaer og tips i denne DUT Guide.

Inden jeg går videre til de didaktiske retningslinjer, vil jeg kort understrege vigtigheden af at skelne mellem undervisningens hensigt og undervisningens indhold. Hensigt og indhold forveksles ofte med hinanden, men vedrører to forskellige didaktiske spørgsmål, nemlig "hvorhen" og "med hvad/gennem hvad". "Genstand og intention kan forekomme identiske, men er det som regel ikke. De ligger oftest langt fra hinanden. Sagt mere præcist: Genstanden bliver først tydelig gennem intentionen" (Heimann, 1961, s. 108. På dansk introduceret i Keiding, 2017). Dette gælder også, når vi som undervisere står med et indhold, der virker som et mål $i$ sig selv; som noget de studerende bør vide. Indholdet er ikke målet, men er noget de studerende bør vide, fordi det har en uddannelsesmæssig værdi, dvs. bidrager til en konkret uddannelsesopgave. Indholdet er, med andre ord, et middel til et mål. Klafki beskriver dette nexus gennem en skelnen mellem indhold (Bildungsinhalt) og indholdets uddannelsesmæssige betydning, altså hvad det bidrager med i forhold til uddannelsen (Bildungsgehalt) (Klafki, 2000, s. 146f.). I Hopmann (2007) italesættes den samme skelnen med begrebsparret "matter" og "meaning". Pointen er hos alle tre, at et givet indhold kan tjene mange forskellige didaktiske formål, og at det ikke er selvforklarende, hvilken hensigt indholdet tjener. Derfor er det afgørende, at indholdsvalg og -analyser gennemføres i tæt dialog med undervisningens hensigt, og at dette samspil formidles til de studerende, således at de ikke blot møder indholdet og forsøger at tilegne sig det (matter), men også ved, hvorfor de møder netop dette emne på dette tidspunkt i deres uddannelse (meaning).

\section{Tip 1}

\section{Hav mod til at vælge fra}

Det første element i Klafkis didaktiske indholdsanalyse er spørgsmålet om det fundamentale (Klafki, 2000, s. 151); altså indhold, der formidler noget man bør vide, noget som konstituerer disciplinen; eksempelvis et grundlæggende princip eller grundlæggende begreb. Ideen om, at der eksisterer et indhold, som enhver studerende bør kende, knytter sig til den såkaldte materiale dannelsestcenkning (Klafki, 1983). Her ses indholdet som værdifuldt eller dannende i sig selv. Vi kender det fra kanon-tænkningen, som oplister værker, der af den ene eller anden grund tilskrives en almen, uddannende værdi. I denne tænkning bliver indholdet - trods 
Heimanns advarsel - tilsyneladende et mål i sig selv, men kun tilsyneladende. For hensigten er netop at kultivere den studerende ind i disciplinen gennem mødet med dette indhold.

Der er forskel på fag. Nogle fag har en tydelig vertikal struktur, hvor der er en vis enighed om en form for kernefaglighed. Andre har en mere horisontal struktur med en række sideordnede positioner (Ulriksen, 2014, s. 123). Noget tyder dog på, at der på tværs af sådanne forskelle eksisterer en forestilling om et fundamentalt indhold i de fleste uddannelser (Keiding \& Hansen, 2012).

En anden ting, der er fælles for alle uddannelser, er problemet med stoftrængsel; altså, at der er meget mere værdifuldt og fundamentalt indhold, end der på nogen måde kan undervises i. Thingholm, Reimer, Keiding, Due, \& Smith (2016: 41) finder således, at omkring halvdelen af både de adspurgte undervisere og studerende svarer, at de studerende giver udtryk for, at de har svært ved at nå at læse pensum. Stoftrængsel kan føre til studiestrategier præget af det, vi kender som "overfladelæring" (Ulriksen, 2014, s. 124ff.). Selve begrebet overfladelæring stammer fra Marton \& Saljö (1976), men genfindes også i bl.a. Biggs \& Tang (2011). Det beskriver det fænomen, at studerende forsøger at huske mest muligt (matter), men ikke får indholdet relateret til formålet med at tilegne sig dette (meaning). Resultatet bliver det, vi kan kalde encyklopædisk viden på bekostning af funktionel viden.

Man må derfor have modet "til at være grundig og til at dvæle intenst ved afgrænsede udvalg" (Wagenschein, 2012, s. 47). Alternativet er, at undervisningens sagsdimension (orden) på niveauet for det lærte curriculum (fx. Keiding \& Qvortrup, 2014, s. 173ff.) formes af, hvad de studerende mere eller mindre tilfældigt husker og glemmer, når de haster sig gennem stoffet.

\section{Tip 2}

\section{Udvælg eksemplariske eksempler og gør det eksemplariske tydeligt}

Det eksemplariske princip knytter sig til den formale dannelsestaenkning. Her er det uddannelsesmæssigt vigtige ikke indholdet i sig selv, men den formning af den studerendes tænke- og handlemåder, som affødes af at beskæftige sig med indholdet. Det kan både være disciplinspecifikke analytiske færdigheder og mere almene kompetencer, som kan tilegnes gennem bearbejdning af tematisk i øvrigt ret forskellige aktiviteter.

Både den materiale og formale dannelsestænkning har fat i noget centralt for vores forståelse af undervisningens indhold, men de overser i kraft af deres ensidighed også, at de både er hinandens forudsætning og et produkt af hinanden. Vi udvikler løbende vores tænkning og handlemuligheder, når vi beskæftiger os med et givet indhold. Vi lærer at lære (Bateson, 2000; Keiding \& Laursen, 2005). Og vi tilegner os også et givet indhold, når vi beskæftiger os med det for at udvikle mere almene færdigheder og kompetencer.

Klafki (1983) forsøger at indfange denne dobbelthed med begrebet kategorial dannelse. Ideen bag begrebet er, at undervisningen må tilbyde analytiske kategorier og begreber, som gør den studerende i stand til at "åbne verden" på måder, som de ellers ikke ville være i stand til. Begrebet føjer noget helt centralt til den formale dannelsestækning. Det er ikke nok, at den studerende beskæftiger sig med eksemplariske problemstillinger. Den studerende skal have støtte til at identificere det almene i det konkrete, hvis de formale kompetencer skal kunne overføres til nye kontekster. Netop dette aspekt af eksemplarisk undervisning bliver for mig at se, ofte overset i undervisning, der henter sit didaktiske grundlag i den formale dannelses- 
tækning, eksempelvis case eller problemorienteret, projektorganiserede undervisning. Risikoen er, at de studerende tilegner sig en række eksempler på faglige problemstillinger uden at opnå en systematisk og klar forståelse af de generelle analytiske begreber og principper bag. Undervisning betyder netop at vise, hvad der ligger under, og dermed altså mere end blot at vise noget.

\section{Tip 3}

\section{Tag højde for de studerendes faglige forudsætninger}

Et helt centralt perspektiv i valg af indhold er de studerendes forudsætninger: Hvad bringer de ind $\mathrm{i}$ undervisningen og på hvilken måde kan et nyt indhold bringes på en form, der gør det begribeligt for de studerende? Sådanne spørgsmål retter opmærksomheden på både indholdsvalg på fagniveau og på fagets placering i den samlede uddannelse, altså struktur og progression. Sidstnævnte vender jeg tilbage til under Tip 7, der vedrører indholdets rækkefølge.

Vi planlægger oftest for den implicitte studerende. Det vil sige, det vi tror eller ønsker, at de studerende ved og kan, når vi møder dem (Ulriksen, 2004). Et alternativ til dette er at forholde sig empirisk til de studerendes forudsætninger og lade indholdsvalget informeres heraf, altså at udøve hvad Helmke (2013) kalder diagnostisk kompetence. Det kan eksempelvis ske gennem korte surveys, hvor de studerendes kendskab til og forståelse af nogle af fagets centrale forudsætninger afdækkes. Først når man ved, hvad de studerende ved, kan man lave en rationel og reflekteret didaktisk planlægning af det videre forløb med det entydige sigte, at de studerende støttes bedst muligt $i$ at realisere fagets uddannelsesmæssige hensigt.

Studerende er forskellige. Vi ved det godt, men ideen om undervisningsdifferentiering, som det at forholde sig didaktisk til den faglige diversitet, er meget lidt udbredt i universitetsuddannelserne. Hvorledes dette gøres praktisk didaktisk afhænger af den konkrete situation. Helt overordnet kan man differentiere inden for alle fire didaktiske kategorier mål/sværhedsgrad, indhold, medier og metoder, herunder den sociale organisering og med forskellige strategier $\mathrm{fx}$ i forhold til behov for støtte, kompensation eller faglige præferencer (Helmke, 2013: 196ff.) I forhold til indholdsdimensionen kan støtte eksempelvis komme på tale, hvis en mindre gruppe af studerende mangler faglige forudsætninger inden for et afgrænset emne. Her kan en model være at udvikle et ekstracurriculært forløb, som disse studerende kan følge. Hvis der er tale om forløb, hvor heterogeniteten knytter sig til, at de studerende kommer fra vidt forskellige uddannelser og skal samarbejde om nye tværfaglige problemstillinger, er det måske snarere en komplementerende strategi i forhold til holdet som helhed, der skal til. Eksempelvis skal studerende fra en uddannelsesbaggrund, fx antropologi, indledningsvist læse introducerende tekster til et andet felt (fx miljøkemi) for at kunne gå i faglig dialog med medstuderende herfra. Og omvendt: studerende fra miljøkemi introduceres til grundlæggende antropologisk viden. Derefter kan hver disciplin bringe egen kernefaglighed i spil i den tværfaglige problemløsning og samtidigt på et helt basalt niveau forstå den anden faglighed. En tredje model kunne være at lade de studerende beskæftige sig med problemstillinger inden for det, deres faglige proeference tilsiger, sådan som vi eksempelvis ser det i frie skriftlige opgaver. 


\section{Tip 4}

\section{Overvej om der er indhold, der er særligt interessant for de studerende}

Hidtil har fokus ligget på indhold og indholdets uddannelsesmæssige værdi i forhold til uddannelsens indre struktur. Der er dog også en udvalgsdimension, som knytter sig til de studerendes oplevelse af, om og hvorledes uddannelsen peger ud mod nutiden og fremtiden, herunder en fremtidig karriere. Klafkis tredje spørgsmål i indholdsanalysen retter sig netop mod dette aspekt af indholdsvalget (Klafki, 2000: 152).

Det kan være aktuelle problemstillinger fra både forskningen, civilsamfundet og erhvervslivet, der optager de studerende, og som samtidigt lever op til kravene for eksemplariske eksempler. I så fald bør de inddrages i undervisningen, således at det bliver tydeligt, at uddannelsens indhold rækker ud over uddannelsen selv og kan bidrage til at åbne verden på måder, som de ellers ikke ville være i stand til. Det kan de aktuelle problemstillinger bidrage til. Resultaterne fra Keiding \& Hansen (2012) tyder dog på, at netop dette aspekt af indholdsvalget ikke spiller en særlig stor rolle, når indholdet vælges og begrundes.

\section{Tip 5}

\section{Overvej om og hvornår forskningen kan bidrage med værdifuldt indhold}

Samspillet mellem forskning og uddannelse kommer til udtryk på mange forskellige måder i en uddannelses curriculum. Helt konkret formulerer Keiding (2018) otte forskellige betydninger af begrebet. I det følgende fokuserer jeg udelukkende på forskningsbasering i betydningen, at underviserens eller fagmiljøets aktuelle forskning bidrager til at definere indholdsvalget (research-led) (Keiding, 2018), fordi de grundlæggende forskellige rationaler i forskning, som produktion af viden og undervisning som formidling af viden ( $\mathrm{fx}$ Keiding \& Qvortrup, 2014, s. 91-102), gør, at spørgsmålet, om hvornår, hvordan og hvorfor forskningen skal komme til syne i undervisningen, bliver helt centralt i universitetsuddannelsernes indholdsdiskussion.

Resultaterne fra Keiding \& Hansen (2012) indikerer, at der er mangfoldige begrundelser for at lade egen eller fagmiljøets forskning indgå som en del af curriculum. På denne ene side finder vi argumenter, der knytter sig til, at uddannelsens faglige profil netop er knyttet til det aktuelle forskningsmiljø. På den anden side, pragmatiske argumenter om, at det er lettere at få faget bemandet, hvis kollegerne selv kan bestemme, hvad de underviser i (sidstnævnte fra upublicerede data fra Keiding \& Hansen, 2012).

Uanset hvilke begrundelser, der er for at inddrage forskningen, er det dog ikke sikkert, at den forskningsmæssige værdi og relevans a priori gør et tema didaktisk relevant. Uddannelser har en helt anden tidslig logik end forskningen. Uddannelser er bygget op om begyndelser og slutninger (Luhmann, 1995), der tager højde for, at nye studerende over en årrække skal indføres systematisk i en disciplin på måder, som gør, at de efter endt uddannelse selv kan udøve disciplinen og vedligeholde egen faglighed. Næste hold studerende starter lige så forudsætningsløst som de foregående hold. Kun underviseren genererer erfaringer på tværs af årgange. I modsætning hertil, forventes det fra forskningen, at en given indsigt ikke blot er ny for den, der frembringer den, men også udvider forskningsfeltets samlede viden; altså at der kontinuert akkumuleres viden som forskeren til en hver tid må være "up to date" med (Luhmann, 1990). 
Dette har betydning for forskningens didaktiske relevans, både set i forhold til de studerendes forudsætninger: Hvornår kan de forstå en given forskningsindsigt? Og set i forhold til uddannelsens samlede indhold: Hvornår er forskningsindsigten for specifik til at leve op til kravet om at uddannelsens indhold skal være både fundamentalt, eksemplarisk og bidrage til kategorial tænkning, og rette sig mod et bredt og ofte ikke specificeret arbejdsliv?

\section{Tip 6}

\section{Forhold dig nuanceret til aftagernes ønsker}

Der har i de seneste år været stigende fokus på uddannelsernes samfundsmæssige relevans. Ud af de i alt 37 anbefalinger fra Udvalget om bedre universitetsuddannelser vedrører ikke mindre end 5 samspillet mellem uddannelse og arbejdsmarked (Udvalg om bedre universitetsuddannelser, 2018). I forhold til indholdsspørgsmålet rejser det en række perspektiver. Historisk set er uddannelsessystemet opstået som et svar på, at den praksisbårne uddannelsesmodel ikke længere kunne modsvare en samfundsmæssig mobilitet samt stigende uforudsigelighed og kompleksitet i samfundets uddannelsesbehov (Keiding \& Qvortrup, 2014, s. 98ff.; Luhmann, 2006, s. 80ff.). Uddannelsernes indhold gik dermed fra at være formet af praksis til at blive et didaktisk anliggende, altså fra deltagelsesorganiseret til curriculumorganiseret. En følge heraf var et nyt problem, nemlig overgangsproblematikken fra uddannelse til arbejdsliv. Pludselig passer en uddannelse til både mange og ingen praksisser. Det betyder selvfølgelig ikke, at forholdet mellem uddannelse og fremtidigt arbejdsliv er helt tilfældigt, og at nogle uddannelser, eksempelvis professionsuddannelserne, synes tættere på fremtidig arbejdspraksis end andre. Ikke desto mindre er overgangen mellem uddannelse og arbejdsliv altid præget af det forhold, at skoleviden skal omsættes til arbejdsviden $\mathrm{i}$ et helt nyt arbejdsfællesskab med egne normer og rutiner (Wahlgren, 2009; Wendlandt \& Rochlen, 2008)

Såvel overdreven som manglende sensitivitet over for omverdenens forventninger kan udfordre en uddannelse. Overdreven sensitivitet kan føre til stoftrængsel og fragmentering af indholdet, dels - paradoksalt nok - til manglende relevans fordi det antal år, der går, fra at et nyt vidensbehov flages af aftagerne, til dimittenderne forlader universitetet, kan have gjort det nye indhold irrelevant for den nugældende praksis. Manglende sensitivitet kan på den anden side føre til, at dimittenderne ikke tilegner sig kompetencer, der over en bred kam anses for vigtige for deres fremtidige beskæftigelse. Anbefalingen er derfor at forholde sig både åbent og kritisk til omverdenens fordringer til uddannelsen, og med et særligt fokus på, hvorvidt en given fordring, $\mathrm{fx}$ digitale kompetencer, faktisk allerede udvikles gennem eksemplariske forløb, og at det i så fald snarere handler om at synliggøre dette over for såvel studerende som aftagere.

\section{Tip 7}

\section{Se dit fag som en del af uddannelsen som helhed}

Det fjerde tema i Klafkis didaktiske indholdsanalyse (Klafki, 2000: 153) knytter sig til spørgsmålet om rækkefølge; altså hvorledes indholdselementerne struktureres tidsligt (Figur 1). De centrale didaktiske begreber er forudsætninger, sammenhænge og progression.

Begrebet sammenhæng betyder her relationer mellem elementer og Klafki peger på vigtigheden af, at det enkelte indholdselement rækker ud over sig selv og bidrager til at forstå me- 
re komplekse problemstillinger. Det har - eller bør have - en uddannelsesmæssig værdi, som rækker ud over det blotte kendskab til sagsforholdet.

Begrebet progression retter opmærksomheden mod, at et givet indholdselement kan være direkte relateret til andre, enten som forudsætning for at kunne forstå noget på et højere taksonomisk niveau på et senere tidspunkt, $\mathrm{fx}$ at kende et begreb for senere at kunne analysere en problemstilling ved hjælp af dette begreb, eller ved at kombinere tidligere elementer til en mere avanceret forståelse af et fænomen.

Spørgsmålet om rækkefølge, og dermed om sammenhænge og progression, peger dels ind $\mathrm{i}$ det enkelte fag, men også ind i uddannelsen som helhed. Dermed er der som oftest tale om beslutninger, som ikke kan træffes af den enkelte underviser, men fordrer dialog i hele underviserkollegiet.

I den forstand udfordrer Klafkis didaktiske analyse forestillingen om, at en underviser "ejer" sit fag og har fuld didaktisk autonomi til at vælge, hvilket indhold de studerende skal beskæftige sig med. I et studenterorienteret perspektiv planlægger underviseren ikke for sig selv, men for de studerendes samlede udbytte af uddannelsen, både inden for det enkelte fag og $\mathrm{i}$ forhold til uddannelsen som helhed. Postareff, Lindblom-Ylänne, and Nevgi (2007) peger på, at en af de mest betydningsfulde effekter af didaktiske kompetenceudvikling er, når udgangspunktet for underviserens didaktiske planlægning går fra et underviserperspektiv til et studenterperspektiv.

Resultaterne fra Keiding \& Hansen (2012) peger på, at de adjunkter, som udgør det empiriske grundlag for artiklen, er ganske opmærksomme på netop spørgsmålet om rækkefølge, og hvorledes indholdet meningsfuldt kan struktureres. Spørgsmålet er, hvorvidt disse indre sammenhænge formidles til de studerende, således at også de studerende kan se det aktuelle indhold i en større faglig sammenhæng? Thingholm m.fl. (2016) har undersøgt henholdsvis undervisere og studerendes opfattelser af en række af de forhold, vi ved, har betydning for højt læringsudbytte. Der blev ikke spurgt direkte til indholdsdimensionen og forståelsen af indholdets betydning for uddannelsen som helhed. Men den store forskel i, hvorvidt undervisere og studerende oplevede, at de faglige mål var klare, tyder på, at nogle aspekter af uddannelsen står væsentligt klarere for underviserne end for de studerende. Således oplevede i gennemsnit $59 \%$ af de studerende og $89 \%$ af underviserne, at de faglige mål var tydeligt defineret (s. 24). Det er som nævnt indledningsvist vigtigt at skelne mellem mål og indhold, men ligeså centralt er det, at indholdet får dets pædagogiske betydning gennem den uddannelsesmæssige hensigt. Og hvis den er uklar, er det også sandsynligt, at den større meningssammenhæng, som et givet indhold indgår i, er uklar - i hvert fald for de studerende. Det betyder, at de studerende overlades med den didaktiske opgave, der ligger i at skabe en meningsfuld sammenhæng mellem de enkelte indholdselementer. De får med andre ord ikke blot ansvar for egen læring, men for egen uddannelse. Spørgsmålet er, om de har forudsætningerne for det, eller om vi overser en vigtig didaktisk opgave her?

Helt konkret skal helhedsperspektivet adresseres på både programmatisk niveau, dvs. i studieordningen, og praktisk-didaktisk, dvs. i tilrettelæggelse af undervisningen. I forbindelse med studieordningsarbejde kan de relevante interessenter bruge "curriculum mapping", der tegner de tematiske linjeføringer gennem hele uddannelsen, således at overlap og huller undgås, og sådan at sammenhæng og progression kan overskues og formidles til alle involverede. I forbindelse med den praktisk-didaktiske tilrettelæggelse vil det være oplagt at drøfte det helt konkrete indhold og dettes didaktiske betydning på tværs af moduler/fag. 


\section{Konklusion}

Ikke overraskende er der ikke et enkelt svar på, hvilket indhold, der skal vælges og med hvilke begrundelser. Jeg har formuleret 7 råd for valg af indhold, som alle identificerer vigtige opmærksomhedspunkter i og begrundelser for indholdsvalget. Læser man på tværs af disse 7 råd, vil man se, at de kan være indbyrdes modstridende. På den ene side skal der tages hensyn til de studerendes aktuelle forudsætninger og gerne også deres interesser og forståelse for indholdets bredere betydning. På den anden side er det enkelte fag forpligtet på uddannelsen som helhed. Lærer de studerende ikke det, der forventes i et fag - måske fordi de ikke har forudsætningerne; måske fordi stoftrængsel og specifikke ønsker fra aftagere eller forskningsmiljøet stod i vejen - står det næste fag i uddannelsens fagrække med andre studenterforudsætninger end forventet. Derfor er indholdsrefleksionen ikke et individuelt, men et kollegialt anliggende, således at den studerende ikke står alene med opgaven med at skabe mening og sammenhæng mellem de enkelte elementer.

\section{Referencer}

Barr, R. B., \& Tagg, J. (1995). From Teaching to Learning - A new paradigm for Undergraduate Education. Change, 27(6), 13-25.

Bateson, G. (2000). The Logical Categories of Learning and Communication. I G. Bateson (Red.), Steps to an Ecology of Mind (s. 279-308). Chicago: Chicago University Pres.

Biggs, J., \& Tang, C. (2011). Teaching for Quality Learning at University: What the Student Does (4. ed.). Berkshire: Open University Pres.

EU. (2015). ECTS Users' Guide. Luxembourg: Publications Office of the European Union Retrieved from http://ec.europa.eu/education/library/publications/2015/ects-usersguide_en.pdf

Heimann, P. (1961). Didaktische Grundbegriffe. I K. Reich \& H. Thomas (Red.), Paul Heimann.

Didaktik als Unterrichtswissenschaft (s. 103-141). Stuttgart: Ernst Klett.

Helmke, A. (2013). Undervisningskvalitet og loererprofessionalitet - diagnostisering, evaluering og udvikling af undervisning. Frederikshavn: Dafolo.

Hopmann, S., Künzli, R., \& Jacobsen, B. W. (1995). Læseplanarbejdets muligheder og begrænsninger. I K. Schnack (Red.), Loeseplansstudier 3 (s. 339-370). København: Danmarks Lærerhøjskole.

Keiding, T. B. (2013). Læringsmålorienteret didaktik. I A. Qvortrup \& M. Wiberg (Red.), Loeringsteori og didaktik (s. 374-394)- København: Hans Reitzel.

Keiding, T. B. (2017). Den læreteoretiske didaktik. I P. F. Laursen \& H. J. Kristensen (Red.), Didaktikhåndbogen (s. 45-68). København: Hans Reitzel.

Keiding, T. B. (2018). Uddannelses- og undervisningskvalitet i didaktisk perspektiv. København: Uddannelses- og Forskningsministeriet. Hentet 8. juni 2019 fra https://ufm.dk/uddannelse/rad-naevn-og-udvalg/udvalg-om-bedreuniversitetsuddannelser/filer/uuu-uddannelses-og-undervisningskvalitet.pdf. 
Keiding, T. B., \& Hansen, J. D. (2012). Undervisningens indhold - universitetsdidaktikkens stedbarn Dansk Universitetspaedagogisk Tidsskrift, 7(13), 105-119.

Keiding, T. B., \& Laursen, E. (2005). Interaktion og Loering. Gregory Batesons bidrag. København: Unge Pædagoger.

Keiding, T. B., \& Qvortrup, A. (2014). Systemteori og didaktik (1. udgave ed.). København: Hans Reitzel.

Keiding, T. B., \& Qvortrup, A. (2017). Higher education journals as didactic frameworks. Higher Education Research \& Development. doi:http://dx.doi.org/10.1080/07294360.2017.1342606

Klafki, W. (1983). Kategorial dannelse. Bidrag til en dannelsesteoretisk fortolkning af den moderne didaktik. In S. E. Nordenbo (Red.), Kategorial dannelse og kritisk konstruktiv paedagogik: Udvalgte artikler (s. 33-72). København: Nyt Nordisk forlag.

Klafki, W. (2000). Didaktik analysis as the core of Preparation of Instruction. I I. Westbury, S. T. Hopmann, \& K. Riquarts (Red.), Teaching as Reflective Practice. Ther German Didaktik Tradition (s. 139-159). London: Lawrence Erlbaum.

Luhmann, N. (1990). Die Wissenschaft der Gesellschaft. Frankfurt am Main: Suhrkamp.

Luhmann, N. (1995). Begyndelser og Slutninger. Betragtninger over forskellene. I J. C. Jacobsen (Red.), Autopoiesis II - udvalgte tekster af Niklas Luhmann (s. 232-243). København: Politisk revy.

Luhmann, N. (2000). Sociale systemer. København: Hans Reitzels.

Luhmann, N. (2006). Samfundets uddannelsessystem. København: Hans Reitzels.

Marton, F., \& Saljö, R. (1976). On qualitative differences in Learning I. The British Journal of Educational Psychology, 46(1), 4-11.

Möller, C. (1973). Technik der Lernplanung. Weinheim Beltz.

Postareff, L., Lindblom-Ylänne, \& Nevgi, A. (2007). The effect of pedagogical training on teaching in higher education. Teaching and teacher education, 23(5), 557-571.

Qvortrup, A., \& Keiding, T. B. (2016). The Mistake to Mistake Learning Theory with Didactics. I G. Christensen, M. Hansbøl, A. Qvortrup, \& M. Wiberg (Red.), On the Definition of Learning (s. 163-187). Odense: Syddansk Universitetsforlag.

Thingholm, H. B., Reimer, D., Keiding, T. B., Due, J., \& Smith, E. (2016). Navigating in Higher Education:. Hentet 8. Juni 2019 fra http://ebooks.au.dk/index.php/aul/catalog/book/162

Udvalg om bedre universitetsuddannelser. (2018). Samlede anbefalinger. Hentet 8. Juni 2019 fra https://ufm.dk/uddannelse/rad-naevn-og-udvalg/udvalg-om-bedreuniversitetsuddannelser/filer/uuu-udvalgets-samlede-anbefalinger.pdf

Ulriksen, L. (2004). Den implicitte studerende. Dansk poedagogisk tidsskrift, 2004, nr. 3, 48-59.

Ulriksen, L. (2014). God undervisning på de videregående uddannelser. En forskningsbaseret brugsbog. Frederiksberg, DK: Frydenlund. 
Wagenschein, M. (2012 [1956]). Om begrebet eksemplarisk undervisning. MONA, 8(4), 42-66.

Wahlgren, B. (2009). Transfer mellem uddannelse og arbejde. Hentet 8. Juni 2019 fra http://nck.au.dk/fileadmin/nck/Opgave_2.5/Transfer__mellem_uddannelse_og_arbejde._Med_summary._Haefte.pdf

Wendlandt, N. M., \& Rochlen, A. B. (2008). Addressing the College-to-Work Transition: Implications for University Career Counselors. Journal of Career Development, 35(2), 151-165. doi:10.1177/0894845308325646 